\title{
Muscle Carnitine Repletion by Long-Term Carnitine Supplementation in Nephropathic Cystinosis
}

\author{
WILLIAM A. GAHL, ISA M. BERNARDINI, MARINOS C. DALAKAS. THOMAS C. MARKELLO. \\ DONNA M. KRASNEWICH, AND LAWRENCE R. CHARNAS \\ Section on Human Biochemical Genetics /W.A.G., I.M.B., T.C.M., D.M.K./ and Unit on Neurogenetics /L.R.C.J. \\ Human Genetics Branch. National Institute of Child Health and Human Development: and Section on \\ Neuromuscular Diseases M.C.D.J. Medical Neurology Branch. National Institute of Neurological Disorders and \\ Stroke. National Institutes of Health. Bethesda. Maryland 20892
}

\begin{abstract}
The renal tubular Fanconi syndrome of children with nephropathic cystinosis causes plasma and musle carnitine depletion. L-Carnitine replacement therapy for up to 18 mo has previously been shown to normalize plasma but not muscle carnitine levels. We treated six cystinosis patients, aged 1 to $4 \mathrm{y}$, with a mean dosage of $92 \mathrm{mg} \mathrm{L}$ carnitine/kg/d given every $6 \mathrm{~h}$ for an average of $62 \mathrm{mo}$. Despite fractional excretions of free carnitine ranging from 55 to $108 \%$, plasma-free and total carnitine concentrations were maintained at or above normal levels. At the end of the carnitine replacement period, the six children had muscle-free carnitine values ranging from 16.0 to 28.0 $\mathrm{nmol} / \mathrm{mg}$ noncollagen protein compared with values of $\mathbf{3 . 0}$ to 11.4 for cystinosis children not supplemented with carnitine [normal, $22.7 \pm 5.0$ (SD) $\mathrm{nmol} / \mathrm{mg}$ protein]. Total muscle carnitine values were also normalized by $L$-carnitine replacement. The monthly increase in total body creatinine production, a measure of muscle mass, was higher $(p=$ $0.036)$ in children with normal plasma free carnitine concentrations $(3.4 \pm 0.9 \mathrm{mg} / \mathrm{d})$ than in children with low plasma free carnitine $(2.3 \pm 0.7 \mathrm{mg} / \mathrm{d})$. No serious side effects, such as severe diarrhea, were observed. We conclude that oral L-carnitine replacement can normalize muscle carnitine content in children with cystinosis. (Pediatr Res 34: 115-119, 1993)
\end{abstract}

Carnitine, or $\beta$-hydroxy-trimethylaminobutyric acid, mediates the transport of long-chain fatty acids into the mitochondrial matrix for subsequent catabolism by $\beta$-oxidation to produce energy $(1,2)$. This process is essential for skeletal muscle $(3)$, which serves as a large reservoir for carnitine (4) but cannot itself synthesize this molecule. Rather, carnitine is synthesized in the liver, kidney, and brain from methionine and lysine (1), and is also supplied by gastrointestinal absorption after the ingestion of meats and milk. Carnitine exists either free or esterified to fatty acids, primarily as acetylcarnitine (1).

In normal individuals, free carnitine is filtered by renal glomeruli and is $97 \%$ reabsorbed by the kidney tubules (5). Patients with renal Fanconi syndrome, however, fail to reabsorb carnitine $(5,6)$ along with other small molecules including water, glucose, amino acids, phosphate, calcium, magnesium, sodium, potassium, and bicarbonate. Typically, free carnitine is only $67 \%$ reabsorbed in Fanconi syndrome, resulting in low plasma carni-

Received December 15, 1992; accepted March 30, 1993

Correspondence and reprint requests: William A. Gahl, M.D., Ph.D. National Institutes of Health, Building 10, Room 9S-242, Bethesda, MD 20892. tine levels (5). Because the circulation provides the only conduit for supplying carnitine to muscle, this results in low muscle carnitine levels $(5,7)$.

Nephropathic cystinosis, a lysosomal storage disease characterized by renal failure at approximately $10 \mathrm{y}$ of age, is the most common identifiable cause of renal tubular Fanconi syndrome in children $(8,9)$. Before receiving a renal transplant, patients with cystinosis have plasma free carnitine concentrations that average $11.7 \pm 4.0$ (SD) $\mu \mathrm{M}$ (normal, $42.0 \pm 9.0 \mu \mathrm{M}$ ) and muscle free carnitine levels averaging $8.3 \pm 1.8 \mathrm{nmol} / \mathrm{mg}$ of noncollagen protein (normal, $22.7 \pm 5.0 \mathrm{nmol} / \mathrm{mg})(5,7)$. The muscle carnitine content of children with cystinosis does not appear to vary with age between 2 and 10 y (7).

Oral carnitine supplementation rapidly normalizes plasma free carnitine concentrations in children with cystinosis. However, carnitine therapy did not appear to correct muscle carnitine depletion even after $18 \mathrm{mo}$, although the results were inconsistent from one individual to another (7). We now present the results of $5 \mathrm{y}$ of carnitine replacement in six cystinosis patients, initially treated at 1 to $4 \mathrm{y}$ of age, with muscle carnitine levels and measurements of total body creatinine production.

\section{MATERIALS AND METHODS}

Subjects. Nephropathic cystinosis was diagnosed based upon the presence of corneal crystals, renal tubular Fanconi syndrome, and elevated leucocyte cystine levels $(8,9)$. Twenty-three affected children aged 0 to $12 \mathrm{y}$ were included in this study, 14 listed in Table 1 and nine additional patients in Table 2. Only patients 1 to 6 received long-term oral L-carnitine therapy with consistently high plasma free carnitine concentrations. All 23 patients had their original, functioning kidneys, with serum creatinine concentrations ranging from 0.5 to $1.7 \mathrm{mg} / \mathrm{dL}(44-150 \mu \mathrm{mol} / \mathrm{L})$. All received replacement of renal losses as needed, generally with phosphate, potassium, and citrate for alkalinization $(8,9)$. The cystine-depleting agents, cysteamine ( $\beta$-mercaptoethylamine) (10) and phosphocysteamine (11), which have proven efficacy in maintaining renal function and enhancing growth in cystinosis $(12,13)$, were administered to all patients at a dosage of 1.3 to $1.95 \mathrm{~g}$ of free base $/ \mathrm{m}^{2} / \mathrm{d}$ divided every $6 \mathrm{~h}$. Affected children were examined as inpatients at the National Institutes of Health Clinical Center every 4 to 6 mo under a protocol approved by the National Institute of Child Health and Human Development Institutional Review Board. Two 24-h urines were routinely collected for creatinine and carnitine during each admission. Informed consent was obtained from all patients or their parents.

Liquid L-carnitine $(100 \mathrm{mg} / \mathrm{mL})$ was a product of Sigma-Tau, Inc. (Gaithersburg, MD). Carnitine was administered at approx- 
Table 1. Muscle carnitine values in cystinosis patients treated and not treated with oral $L$-carnitine

\begin{tabular}{|c|c|c|c|c|c|}
\hline \multirow[b]{3}{*}{ Patients* } & \multirow{3}{*}{$\begin{array}{l}\text { Age } \\
(\mathrm{mo})\end{array}$} & \multicolumn{2}{|c|}{ L-carnitine replacement } & \multirow{2}{*}{\multicolumn{2}{|c|}{$\begin{array}{c}\text { Muscle } \\
\text { carnitine } \\
\text { (nmol/mg } \\
\text { protein) }\end{array}$}} \\
\hline & & \multirow{2}{*}{$\begin{array}{l}\text { Mean dosage } \\
(\mathrm{mg} / \mathrm{kg} / \mathrm{d})\end{array}$} & \multirow{2}{*}{$\begin{array}{l}\text { Duration } \\
\text { (mo) }\end{array}$} & & \\
\hline & & & & Free & Total \\
\hline \multicolumn{6}{|l|}{ Treated } \\
\hline 1 & 69 & 83 & 54 & 16.0 & 20.0 \\
\hline 2 & 81 & 97 & 61 & 19.3 & 25.4 \\
\hline 3 & 83 & 84 & 56 & 16.4 & 26.2 \\
\hline 4 & 85 & 98 & 62 & 20.6 & 32.9 \\
\hline 5 & 91 & 111 & 59 & 28.0 & 34.1 \\
\hline 6 & 136 & 78 & 79 & 17.9 & 23.8 \\
\hline Mean & 91 & 92 & 62 & 19.7 & $27.1+$ \\
\hline SD & 23 & 12 & 9 & 4.4 & 5.4 \\
\hline \multicolumn{6}{|l|}{ Not treated } \\
\hline $6 \ddagger$ & 57 & & & $11.4 \$$ & 15.9 \\
\hline 7 & 67 & & & $10.0 \$$ & 14.8 \\
\hline 8 & 74 & & & $7.7 \$$ & 10.1 \\
\hline 9 & 79 & & & $7.9 \$$ & 11.7 \\
\hline 10 & 80 & & & $6.8 \$$ & 7.4 \\
\hline 11 & 109 & & & $8.7 \$$ & 11.5 \\
\hline 12 & 114 & & & $8.8 \$$ & 9.1 \\
\hline 13 & 120 & & & 9.9 & 12.9 \\
\hline 14 & 143 & & & 3.0 & 4.4 \\
\hline Mean & 94 & & & 8.2 & 10.9 \\
\hline $\mathrm{SD}$ & 29 & & & 2.4 & 3.6 \\
\hline \multicolumn{6}{|l|}{ Normal } \\
\hline Mean & & & & 22.7 & 27.9 \\
\hline SD & & & & 5.0 & 7.7 \\
\hline$n$ & & & & 6 & 6 \\
\hline
\end{tabular}

* The mean plasma free carnitine of the treated patients was $54 \pm 14$ (SD) $\mu \mathrm{M}$ compared with $14 \pm 5 \mu \mathrm{M}$ for the untreated group (normal. $42 \pm 9.0 \mu \mathrm{M})$.

+ Different from "not treated" mean at $p<0.001$

$\ddagger$ Before L-carnitine replacement.

$\$$ These values have been previously reported (7).

imately $100 \mathrm{mg} / \mathrm{kg} / \mathrm{d}(0.62 \mathrm{mmol} / \mathrm{kg} / \mathrm{d})$ in divided doses given every $6 \mathrm{~h}$.

Materials. $1-{ }^{14} \mathrm{C}$-acetyl $\mathrm{CoA}(50 \mathrm{mCi} / \mathrm{mmol})$ was obtained from New England Nuclear (Boston, MA) and from ICN Pharmaceuticals (Irvine, CA, and Plainview, NJ), which also supplied sodium tetrathionate. Ultrapure Tris was from BoehringerMannheim Biochemicals (Indianapolis, IN), and AG1-X8 resin, 200- to 400-mesh, was from Bio-Rad Laboratories (Richmond, CA). Acetyl CoA, L-carnitine, and carnitine acetyltransferase were products of Sigma Chemical Co. (St. Louis, MO).

Methods. Free and total carnitine in plasma and urine were assayed according to McGarry and Foster (14), as previously described (5). Fractional excretion of carnitine was calculated as $100 \times$ (urine carnitine $\times$ serum creatinine)/(serum carnitine $\times$ urine creatinine). Muscle carnitine was measured as described (15). Open or needle muscle biopsies, taken from the quadriceps muscle, were fresh-frozen in isopentane, cooled to $-160^{\circ} \mathrm{C}$ in liquid nitrogen, and processed for oil-red-O staining, as described (16). Creatinine was assayed by a modification of the Jaffe reaction (17), and protein by the bicinchoninic acid method (18).

Statistics. Group comparisons used $t$ test. Rates of increase of daily urinary creatinine excretion were determined by linear regression analysis.

\section{RESULTS}

Six children with cystinosis, ages $15,20,27,23,32$, and 57 mo, had plasma free carnitine concentrations of 5 to $18 \mu \mathrm{M}$ (normal, $42 \pm 9 \mu \mathrm{M}$ ) before carnitine supplementation (Fig. 1A).
Total carnitine concentrations varied between 5 and $29 \mu \mathrm{M}$ (normal, $52.3 \pm 11.4 \mu \mathrm{M}$ ) (Fig. $1 B$ ). Oral L-carnitine replacement was initiated at a mean dosage of $92 \mathrm{mg} / \mathrm{kg} / \mathrm{d}$ for a mean duration of 62 mo (Table 1). Plasma free and total carnitine concentrations, which normalize within hours after the start of therapy (7), were maintained at or above normal levels in each patient throughout the treatment period (Figs. $1 A$ and $B$ ).

Before carnitine replacement, the fractional excretion of free carnitine ranged from 21 to $38 \%$ in the six children subsequently treated (Fig. 2). Over the subsequent years of carnitine supplementation, the mean fractional excretion of free carnitine was maintained between 55 and $108 \%$.

At the end of the period of carnitine replacement, the six patients had a mean age of 91 mo (range, 69-136 mo) and normal mean free and total carnitine levels in their muscle, i.e. 19.7 and $27.1 \mathrm{nmol} / \mathrm{mg}$ noncollagen protein, respectively (Table 1). Each individual child also had free and total muscle carnitine values within the normal range. This was in striking contrast to the muscle carnitine values in nine cystinosis patients, aged 57 to $143 \mathrm{mo}$, who never received carnitine; all had low muscle carnitines, with mean free and total carnitine levels of 8.2 and $10.9 \mathrm{nmol} / \mathrm{mg}$ noncollagen protein, respectively $(p<0.001)$.

One of the most objective measures of increased muscle mass and function is urinary creatinine excretion, because creatinine is a characteristic end-product of muscle metabolism. Therefore, we measured the monthly rate of increase in creatinine production, as gauged by 24-h urinary excretion, in a total of 15 cystinosis children (Table 2). These patients were selected based upon their ages, lack of renal failure, and mean plasma free carnitine values, which spanned a broad range from 8 to $71 \mu \mathrm{M}$. The patients were chosen without a priori knowledge of their rates of increase in urinary creatinine excretion. They were divided into two groups. In one group were the six children with low plasma free carnitine values $(\leq 22 \mu \mathrm{M})$. In the other were the nine children with normal plasma free carnitine values $(>30$ $\mu \mathrm{M})$, including patients 1 to 6 and two patients (21 and 22) who did not receive carnitine replacement. The mean \pm SD monthly increase in creatinine excretion for the nine children with normal carnitines was $3.4 \pm 0.9 \mathrm{mg} / \mathrm{d}$. This was significantly greater than the mean $\pm \mathrm{SD}(2.3 \pm 0.7 \mathrm{mg} / \mathrm{d})$ for the six children with low plasma free carnitine concentrations $(p=0.036)$. The two subgroups had similar mean ages and durations of follow-up.

Despite the normalization of muscle carnitine levels by carnitine supplementation, treated patients showed no reduction in the number of lipid droplets apparent on oil-red-O staining of their muscle biopsies (data not shown).

None of the children treated long-term with oral L-carnitine experienced any of the known side effects of therapy, including nausea, vomiting, diarrhea, or a fish-like odor to their breath and skin.

\section{DISCUSSION}

Carnitine deficiency in man can have a wide variety of causes. including inadequate dietary intake or gastrointestinal absorption (19), impaired hepatic synthesis (20), increased removal by hemodialysis $(21,22)$, deficient transport at the level of the plasma membrane (23-25) or inner mitochondrial membrane (26), excessive esterification by fatty acids that accumulate due to shortchain (27) or medium-chain (4) acyl-CoA dehydrogenase deficiency, binding by medications such as valproic acid (28) or pivalate $(29)$, and inordinate renal losses $(5,6)$. Patients with carnitine deficiency involving the plasma, muscle, and liver may exhibit a cardiomyopathy or a Reye-like syndrome with encephalopathy and hypoglycemia $(20,24,30,31)$. Other patients, such as those with renal tubular Fanconi syndrome, have carnitine deficiency involving the plasma and muscle compartments; the liver, supplied by the portal circulation and by de novo synthesis. has not been demonstrated to be carnitine-deficient in these patients, although liver biopsies have not been performed. 
Table 2. Rate of increase in daily creatinine production for cystinosis children with different plasma free carnitine concentrations*

\begin{tabular}{|c|c|c|c|c|c|c|c|}
\hline Patient & $\begin{array}{l}\text { Aget } \\
(\mathrm{mo})\end{array}$ & $\begin{array}{c}\text { Creatinine } \\
\text { Clearancet } \\
\left(\mathrm{mL} / \mathrm{min} / 1.73 \mathrm{~m}^{2}\right)\end{array}$ & $\begin{array}{l}\text { Carnitine } \\
\text { therapy } \neq\end{array}$ & $\begin{array}{c}\text { Duration of } \\
\text { follow-up } \\
\text { (mo) }\end{array}$ & $\begin{array}{c}\text { No. of } \\
\text { visits }\end{array}$ & $\begin{array}{c}\text { Mean } \\
\text { plasma free } \\
\text { carnitine } \\
(\mu \mathrm{M})\end{array}$ & $\begin{array}{c}\text { Monthly increase in } \\
\text { daily creatinine } \\
\text { production } \\
(\mathrm{mg})\end{array}$ \\
\hline \multicolumn{8}{|l|}{ Low carnitine } \\
\hline 15 & 114 & 28 & $N$ & 64 & 11 & 8 & 1.4 \\
\hline 16 & 116 & 26 & $\mathrm{~N}$ & 61 & 9 & 12 & 3.3 \\
\hline 17 & 56 & 33 & $N$ & 43 & 9 & 13 & 2.8 \\
\hline 18 & 48 & 43 & $N$ & 46 & 13 & 14 & 1.8 \\
\hline 19 & 158 & 53 & $\mathrm{~N}$ & 92 & 11 & 16 & 2.3 \\
\hline 20 & 140 & 16 & $N$ & 67 & 13 & 22 & 2.4 \\
\hline \multirow[t]{2}{*}{ Mean \pm SD } & 105 & 33 & & 62 & 11 & 14 & 2.3 \\
\hline & 44 & 13 & & 18 & 2 & 5 & 0.7 \\
\hline \multicolumn{8}{|l|}{ Normal carnitine } \\
\hline 21 & 103 & 39 & $N$ & 59 & 15 & 30 & 4.8 \\
\hline 22 & 100 & 39 & $N$ & 51 & 11 & 31 & 2.1 \\
\hline 23 & 77 & 51 & $\mathrm{Y}$ & 57 & 14 & 32 & 3.6 \\
\hline 4 & 79 & 83 & $\mathrm{Y}$ & 47 & 12 & 36 & 4.5 \\
\hline 3 & 81 & 67 & $\mathrm{Y}$ & 60 & 11 & 42 & 2.7 \\
\hline 1 & 69 & 46 & $\mathrm{Y}$ & 54 & 12 & 47 & 2.9 \\
\hline 5 & 91 & 72 & $\mathrm{Y}$ & 56 & 12 & 62 & 2.5 \\
\hline 2 & 81 & 49 & $\mathrm{Y}$ & 50 & 12 & 64 & 3.1 \\
\hline 6 & 136 & 40 & $\mathrm{Y}$ & 82 & 13 & 71 & 4.2 \\
\hline \multirow[t]{2}{*}{ Mean \pm SD } & 91 & 54 & & 57 & 12 & 46 & $3.4 \$$ \\
\hline & 20 & 16 & & 10 & 1 & 16 & 0.9 \\
\hline
\end{tabular}

* Fifteen cystinosis children, on whom urinary creatinine data were available for at least 43 mo, were ordered according to their mean plasma free carnitine concentrations. The mean ages for patients with low and normal plasma carnitine values were 75 and 62 mo, respectively. Patients 1 to 6 are as listed in Table 1. For each patient, the rate of increase in daily creatinine excretion, based upon nine to 15 regular inpatient $24-\mathrm{h}$ urine collections per patient, was calculated by linear regression analysis and expressed as a monthly increase. in mg. For 13 of the 15 patients, the data fit a linear model, with correlation coefficients between 0.67 and 0.95 . Normal daily creatinine excretion is $22 \mathrm{mg} / \mathrm{kg}$ body weight $(35,36)$. Based upon normal growth between 3 and $8 \mathrm{y}$ of age, the expected monthly increase in daily creatinine production would be $3.8 \mathrm{mg}$.

+ At time of end-analysis

$\ddagger Y$, yes; $N$, no.

$\$$ Different from "low carnitine" mean at $p=0.036$.

The intent of carnitine replacement therapy in Fanconi syndrome is to restore muscle carnitine levels to normal. This has been difficult to accomplish, despite rapid normalization of plasma carnitine levels. Four of six cystinosis patients failed to exhibit any increase in muscle carnitine levels after up to $18 \mathrm{mo}$ of supplementation (7). Whether due to poor compliance in these patients or some other reason, this finding has tempered enthusiasm for treating cystinosis patients with oral L-carnitine and has raised the issue of why the muscle is so refractory to repletion.

Skeletal muscle uptake of carnitine has been studied in human myotubes in culture (32-34). The process has been shown to have two active transport components, one with high affinity $(\mathrm{Km}=2-5 \mu \mathrm{M})$ and one with low affinity $(\mathrm{Km}=14-160 \mu \mathrm{M})$ $(33,34)$. Although the plasma carnitine concentration in treated patients is within the range of the $\mathrm{Km}$ for transport in isolated cells, other factors, such as accessibility to blood supply or competition for transport, may come into play in vivo. Thus, very long-term therapy might be required to replete the huge muscle carnitine compartment.

In fact, approximately 5 y of L-carnitine replacement successfully accomplished this feat (Table 1), even in the face of large ongoing renal losses of carnitine (Fig. 2). By maintaining plasma free and total carnitine in the normal range (Fig. 1), one 4-y-old child (patient 6 ) restored his muscle carnitine to normal by age 11 , and five others had normal muscle carnitine levels at 5 to 7 $y$ of age (Table 1). We did not determine whether these five had muscle carnitine deficiency at the start of therapy because it was clear that they would develop muscle carnitine deficiency by 5 to $7 \mathrm{y}$ of age if not supplemented (7). All six initially had plasma carnitine deficiency, and all previously biopsied 5- to 7-y-old cystinosis patients, without carnitine replacement, have exhibited muscle carnitine deficiency (Table 1).
How can the beneficial effects of carnitine therapy be gauged in young children with cystinosis? Objective measures of wellbeing such as activity level, muscle strength, and endurance are poorly tested in this age group. Growth in height and weight are affected by a vast number of variables and are insensitive outcome parameters, especially in individuals with a chronic disease affecting growth. Similarly, our study showed no correlation between the number of lipid droplets on oil-red-O staining and the improved muscle carnitine status of the children, suggesting that this histologic technique is not sufficiently quantifiable or that other reasons exist for lipid accumulation in the muscles of these patients.

On the other hand, several findings support the possible efficacy of carnitine replacement in children with cystinosis. First, plasma carnitine levels were rapidly and consistently normalized (Fig. 1). Second, plasma FFA have previously been demonstrated to fall with carnitine therapy (7). Finally, normalization of muscle carnitine levels was associated with a rise in creatinine production, which correlates well with lean body mass in adults $(r=$ $0.88)(35)$ and children (36). This encouraging finding must be balanced, however, by recognition that our observations were retrospective, involved a small number of patients, and revealed a relatively small difference between carnitine-replete and carnitine-deficient patients. Furthermore, the normal value for the rate of increase in daily creatinine production has not been experimentally determined, so the clinical significance of this parameter is speculative. One child with a plasma free carnitine concentration of $12 \mu \mathrm{M}$ had robust creatinine production (Table 2).

What dosage of L-carnitine should be used for carnitinedeficient children with cystinosis? Several studies have demonstrated that gastrointestinal absorption of L-carnitine is slow and incomplete in humans (37-39). Extremely high dosages can be 

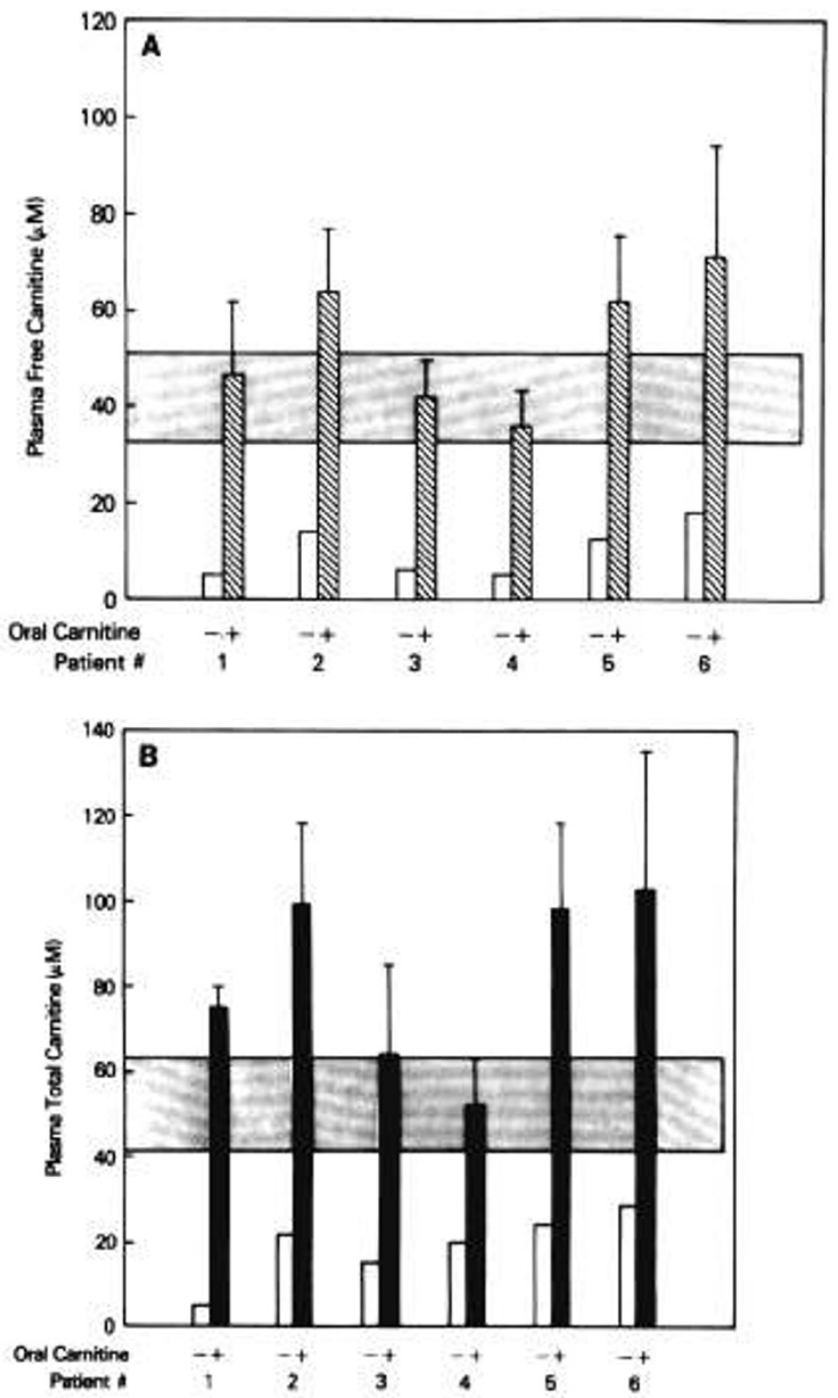

Fig. 1. Plasma carnitine concentrations before $(-)$ and after $(+)$ longterm L-carnitine replacement in six cystinosis children. $A$, Free carnitine; $B$, total carnitine. Values during carnitine replacement are means of between 10 and 19 determinations over 54 to 79 mo. Bars show SD. The normal mean $\pm 1 \mathrm{SD}$ is depicted by the shaded rectangle.

associated with side effects such as diarrhea, nausea and vomiting, and a fishy body odor (40). Our patients maintained normal or elevated plasma free and total carnitine levels when given 78 to $111 \mathrm{mg} / \mathrm{kg} / \mathrm{d}$ even in the face of substantial urinary carnitine wasting (Fig. 2). Therefore, we recommend a starting dosage of 50 to $100 \mathrm{mg} / \mathrm{kg} / \mathrm{d}$, titrated to maintain plasma carnitine levels in the normal range without side effects. Although giving the daily dose divided every $6 \mathrm{~h}$ resulted in excellent muscle repletion, oral L-carnitine might prove equally effective when given less frequently.

Before L-carnitine therapy for renal Fanconi syndrome, most cystinosis patients had plasma carnitine deficiency, and none had a normal muscle carnitine content $(5,7)$. However, all six children with cystinosis who were treated for $5 \mathrm{y}$ with oral $\mathrm{L}$ carnitine had normal muscle carnitine levels. Carnitine replacement in this population will become an increasingly important issue as patients retain their native kidneys for longer periods of time by virtue of therapy with the cystine-depleting agent, cysteamine $(12,13)$. Unfortunately, this drug does not restore tubular function $(9,12)$, so the native kidneys of cysteaminetreated cystinosis patients continue to spill carnitine. As a result cysteamine therapy potentially prolongs the duration of muscle carnitine deficiency in pretransplant patients. The ultimate clin-

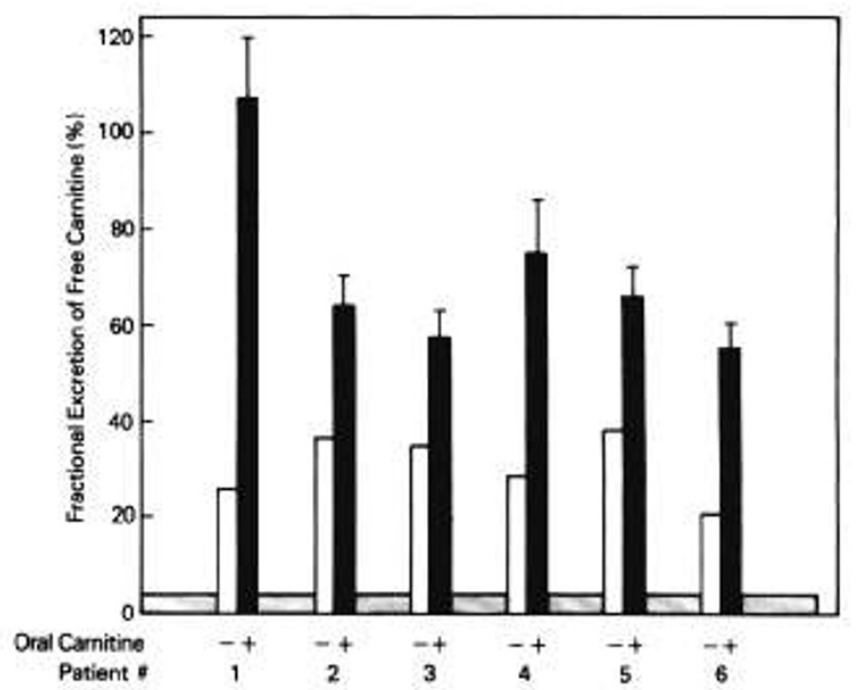

Fig. 2. Fractional excretion of free carnitine before $(-)$ and after $(+)$ L-carnitine replacement in six cystinosis children. Error bars show SEM: shaded area is the normal range for fractional excretion of free carnitine.

ical benefits of early carnitine therapy must still be determined; this will require a controlled study involving a large group of patients who are old enough to be tested objectively for muscle strength and activity.

\section{REFERENCES}

1. Broquist HP 1982 Carnitine biosynthesis and function. Fed Proc 41:28402842

2. Hoppel CL 1982 Carnitine and carnitine palmitoyltransferase in fatty acid oxidation and ketosis. Fed Proc 41:2853-2857

3. Long CS. Haller RG, Foster DW, McGarry JD 1982 Kinetics of carnitinedependent fatty acid oxidation: implications for human carnitine deficiency. Neurology 32:663-666

4. Rebouche CJ, Engel AG 1984 Kinetic compartmental analysis of carnitine metabolism in the human carnitine deficiency syndromes. Evidence for alterations in tissue carnitine transport. $\mathrm{J}$ Clin Invest 73:857-867

5. Bernardini I, Rizzo WB, Dalakas M, Bernar J, Gahl WA 1985 Plasma and muscle free carnitine deficiency due to renal Fanconi syndrome. J Clin Invest 75:1124-1130

6. Steinman B, Bachmann C, Colombo J.P, Gitzelmann R 1987 The rena handling of carnitine in patients with selective tubulopathy and with Fanconi syndrome. Pediatr Res 21:201-204

7. Gahl WA, Bernardini I, Dalakas M, Rizzo WB, Harper GS, Hoeg JM, Hurko O, Bernar J 1988 Oral carnitine therapy in children with cystinosis and renal Fanconi syndrome. J Clin Invest 81:549-560

8. Gahl WA 1986 Cystinosis coming of age. Adv Pediatr 33:95-126

9. Gahl WA, Renlund M, Thoene JG 1989 Lysosomal transport disorders: cystinosis and sialic acid storage disorders. In: Scriver CR, Beaudet AL, Sly WS, Valle D (eds) The Metabolic Basis of Inherited Disease. McGraw-Hill, New York, pp 2619-2647

10. Thoene JG, Oshima RG, Crawhall JC, Olson DL, Schneider JA 1976 Intracellular cystine depletion by aminothiols in vitro and in vivo. J Clin Inves 58:180-189

11. Smolin LA, Clark KF, Thoene JG, Gahl WA, Schneider JA 1988 A comparison of the effectiveness of cysteamine and phosphocysteamine in elevating plasma cysteamine concentration and decreasing leukocyte free cystine in nephropathic cystinosis. Pediatr Res 23:616-620

12. Gahl WA, Reed GF. Thoene JG, Schulman JD, Rizzo WB, Jonas AJ, Denman DW, Schlesselman JJ, Corden BJ. Schneider JA 1987 Cysteamine therapy for children with nephropathic cystinosis. N Engl J Med 316:971-977

13. Clark KF. Franklin PS, Reisch JS, Hoffman HJ, Gahl WA, Thoene JG Schneider JA 1992 Effect of cysteamine- $\mathrm{HCl}$ and phosphocysteamine dosage on renal function and growth in children with nephropathic cystinosis. Clin Res 40:1 13A(abstr)

14. McGarry JD, Foster DW 1976 An improved and simplified radioisotopic assay for the determination of free and esterified carnitine. J Lipid Res 17:277281

15. Cederblad G, Lindstedt S, Lundholm K 1974 Concentration of carnitine in human muscle tissue. Clin Chim Acta 53:311-321

16. Engel WK 1970 Selective and nonselective susceptibility of muscle fiber types a new approach to human neuromuscular diseases. Arch Neurol 22:97-117

17. Heinegard D, Tiderstrom G 1973 Determination of serum creatinine by a direct colorimetric method. Clin Chim Acta 43:305-310

18. Smith PK, Krohn RI, Hermanson GT, Mallia AK, Gartner FH, Provenzano MD, Fujimoto EK, Goeke NM, Olson BJ, Klenk DC 1985 Measurement of protein using bicinchoninic acid. Anal Biochem 150:76-85 
19. Schmidt-Sommerfeld E, Penn D, Wolf H 1983 Carnitine deficiency in premature infants receiving total parenteral nutrition: effect of L-carnitine supplementation. J Pediatr 102:931-935

20. Rebouche CJ, Engel AG 1983 Carnitine metabolism and deficiency syndromes. Mayo Clin Proc 58:533-540

21. Bohmer T. Bergrem H. Eiklid K 1978 Carnitine deficiency induced during intermittent haemodialysis for renal failure. Lancet 1:126-128

22. Moorthy AV, Rosenblum M, Rajaram R, Shug AL 1983 A comparison of plasma and muscle carnitine levels in patients on peritoneal or hemodialysis for chronic renal failure. Am J Nephrol 3:205-208

23. Treem WR, Stanley CA. Finegold DN. Hale DE, Coates PM 1988 Primary carnitine deficiency due to a failure of carnitine transport in kidney, muscle and fibroblasts. N Engl J Med 319:1331-1336

24. Stanley CA, DeLeeuw S, Coates PM, Vianey-Liaud C, Divry P. Bonnefont JP. Saudubcay JM, Haymond M. Trefz FK. Breningstall GN, Wappner RS. Byrd DJ, Sansarica C. Tein I, Grover W, Valle D, Rutledge SL. Treem WR 1991 Chronic cardiomyopathy and weakness or acute coma in children with a defect in carnitine uptake. Ann Neurol 30:709-716

25. Tein I, De Vivo DC, Bierman F, Pulver P, De Meirleir LJ, Cvitanovic-Sojat L, Pagon RA, Bertini E, Dionisi-Vici C, Servidei S, DiMauro S 1990 Impaired skin fibroblast carnitine uptake in primary systemic carnitine deficiency manifested by childhood carnitine-responsive cardiomyopathy. Pediatr Res 28:247-255

26. Stanley CA. Hale DE, Berry GT, DeLeeuw S, Boxer J. Bonnefont J-P 1992 Brief report: a deficiency of carnitine acylcarnitine translocase in the inner mitochondrial membrane. N Engl J Med 327:19-23

27. Turnbull DM, Bartlett K. Stevens DL, Alberti KGMM, Gibson GJ, Johnson MA, McCulloch AJ, Sherratt HSA 1984 Short-chain acyl-CoA dehydrogenase deficiency associated with a lipid-storage myopathy and secondary carnitine deficiency. N Engl J Med 311:1232-1236

28. Böhles H, Richter K, Wagner-Thiessen E, Schafer H 1982 Decreased serum carnitine in valproate induced Reye syndrome. Eur J Pediatr 139:185-186

29. Holme E. Jacobson CE, Nordin I. Greter J, Lindstedt S, Kristiansson B, Jodal
U 1989 Carnitine deficiency induced by pivampicillin and pivmecillinam therapy. Lancet 2:469-473

30. Parker D, Root AW, Schimmel S, Andriola M, DiMauro S 1982 Encephalopathy and fatal myopathy in two siblings. Am J Dis Child 136:598-601

31. Chapoy PR, Angelini C, Brown WJ. Stiff JE, Shug AL. Cederbaum SD 1980 Systemic carnitine deficiency: a treatable inherited lipid-storage disease presenting as Reye's syndrome. N Engl J Med 303:1389-1394

32. Harper GS. Bernardini I, Hurko O. Zuurveld J, Gahl WA 1987 Cystine storage in cultured myotubes from patients with nephropathic cystinosis. Biochem J 243:84!-845

33. Martinuzzi A. Vergani L. Rosa M. Angelini C 1991 L-carnitine uptake in differentiating human cultured muscle. Biochim Biophys Acta 1095:217222

34. Rebouche CJ, Engel AG 1982 Carnitine transport in cultured muscle cells and skin fibroblasts from patients with primary systemic carnitine deficiency. In Vitro 18:495-500

35. Calloway DH, Margen S 1971 Variation in endogenous nitrogen excretion and dietary nitrogen utilization as determinants of human protein requirement. J Nutr 101:205-216

36. Schwartz GJ, Feld LG, Langford DJ 1984 A simple estimate of glomerular filtration rate in full-term infants during the first year of life. J Pediatr 104:849-854

37. Hamilton JW, Li BU, Shug AL, Olson WA 1986 Carnitine transport in human intestinal biopsy specimens. Demonstration of an active transport system. Gastroenterology $91: 10-16$

38. Harper P, Elwin C-E, Cederblad G 1988 Pharmacokinetics of intravenous and oral bolus doses of L-carnitine in healthy subjects. Eur J Clin Pharmacol 35:555-562

39. Rebouche CJ 1991 Quantitative estimation of absorption and degradation of a carnitine supplement by human adults. Metabolism 40:1305-1310

40. Petrykowski WV, Ketelsen U-P, Schmidt-Sommerfeld E, Penn D, Sawicka E. Struck E, Lehnert W, Happ K, Strassburg H-M 1985 Primary systemic carnitine deficiency under successful therapy: clinical, biochemical, ultrahistochemical and renal clearance studies. Clin Neuropathol 4:63-71 